\title{
THE CAREERS OF CALVINIST STIPENDIARIES FROM THE GRAND DUCHY OF LITHUANIA IN THE 17TH CENTURY. THE EXAMPLE OF GABRIEL DYJAKIEWICZ
}

\author{
Elżbieta Bagińska
}

ABSTRACT This article applies to a minister of the Calvinist Church in the Grand Duchy of Lithuania, Gabriel Dyjakiewicz (1660-1724), who became the superintendent of Unitas Lithuaniae (the Lithuanian Brethren) in the Podlasie district and proved to be a remarkable figure. His career was launched successfully thanks to the scholarships given to him. The text is primarily based on memoirs written by him of almost his whole life, and archival documents in the collection of the Reformed Synod, mainly held by the Wróblewski Library of the Lithuanian Academy of Sciences in Vilnius. The education of Dyjakiewicz consisted of several stages: first, only a twoyear study in the Grammar School in Slutsk, where he received a private scholarship for further education, this time in Protestant university centres. Second, studies at the University of Königsberg and the University of Leiden. In the last case, Dyjakiewicz most likely benefited from a scholarship which he had received from Unitas Lithuaniae. The author briefly characterises both the nature of the grammar school and the two universities, and the obligations which rested on bursary holders. The rest of the article is devoted to the professional and public activities of Dyjakiewicz.

Gabriel Dyjakiewicz, the superintendent of Unitas Lithuaniae (the Lithuanian Brethren) in the Podlasie District, proved to be a remarkable figure, whose administrative and pastoral activities, ambitions and range of interests definitely went beyond his official duties in his parish or district. In spite of the fact that he used to be well respected and highly regarded by his contemporaries, despite his extensive public activities, and, last but not least, despite the memoirs he wrote, nowadays he seldom appears in pages of monographs or scholarly periodicals. ${ }^{1}$ Most attention and content was devoted to him

${ }^{1}$ G. Dyjakiewicz, Memoriale pielgrzymstwa, pracy, zabaw w tej śmiertelności żywota ziemskiego księdza Gabriela z Kolimata Dyjakiewicza, kaznodzieje stowa Pana Jezusowego we zborach przez Ewangeliq Święta Reformowanych w Wielkim Księstwie Litewskim będacych, sporzadzone solentis 1692, LMAB RS, F. 40, b. 410 . 
by Wojciech Kriegseisen, ${ }^{2}$ and only some by Tadeusz Wyszomirski, ${ }^{3}$ who writes about the Węgrów congregation, and Władysław Gizbert Studnicki. 4

Gabriel Dyjakiewicz (b. 1660) was the son of Stefan Dyjakiewicz from Kolimaty, the senior (superintendent) of the Dubiny congregation, and Apolonia Falecka. He started his education, according to his memoirs, relatively late, and only at the age of 20 did he begin to learn Latin. In order to continue his education, he was sent to a grammar school in Slutsk, along with Jan Niezabitowski, the son of Stanisław Niezabitowski, the cup-bearer of Kalisz. Slutsk Grammar School, with its focus on the humanities (specialising in languages, grammar and rhetoric) was typical and common among Calvinist schools, both in the Kingdom of Poland (Pińczów, Bełżyce) ${ }^{5}$ and the Grand Duchy of Lithuania. Its curriculum was approved at the provincial Synod in Vilnius on 29 June 1629, and was meant to apply to all Lithuanian secondary schools. The grammar school offered four years of instruction, starting with the form grade and ending with the first, which equalled the number of teachers, although not always. Compendium latinae grammaticae pro discentibus scriptum..., by Jan Rhenius, was used to teach Latin grammar, and Grammaticae educationis puerilis linguae graecae..., by Teofil Golius, to teach Greek grammar; Orationes selectae, by Titus Livius, helped to teach rhetoric, elocution and history; ethics was introduced with the help of De Officiis by Cicero; while the Heidelberg Cathechism ${ }^{6}$ served as a reference text in religion classes. In their senior year of school (first form), students were expected to have a good command of Latin and Greek to be able to follow the wide curriculum. Thus, the information in his memoirs that Dyjakiewicz started learning Latin only at the age of 20 does not seem to be accurate, especially if one

${ }^{2}$ W. Kriegseisen, Ewangelicy polscy i litewscy w epoce saskiej (1696-1763) (Warsaw, 1996).

${ }^{3} \mathrm{~T}$. Wyszomirski, 'Z przeszłości zboru protestanckiego w Węgrowie w XVII i XVIII wieku', Odrodzenie i Reformacja w Polsce, 4 (1959), pp. 137-55.

${ }^{4}$ W. Gizbert Studnicki, Gabriel z Kolimata Dyjakiewicz (1660-1724), Polski słownik biograficzny [PSB], (Kraków, 1948), VI, pp. 53-4.

${ }^{5} \mathrm{~S}$. Tworek, Działalność oświatowo-kulturalna kalwinizmu małopolskiego (połowa XVI-połowa XVIII wieku) (Lublin, 1970), pp. 6-64, 172-5.

${ }^{6}$ Idem, 'Programy nauczania i prawa gimnazjum kalwińskiego w Kiejdanach z lat 1629 i 1685', Odrodzenie i Reformacja w Polsce, 15 (1970), pp. 226-7; M. Jarczykowa, 'Program nauczania liceum w Słucku. Z dziejów szkolnictwa kalwińskiego w XVII wieku', Studia bibliologiczne, 12 (2000), pp. 120-6. 
still remembers his first form (senior year) enrolment. ${ }^{7}$ However, he must have demonstrated ability and diligence in his school work, since it took him only two years in Slutsk to be awarded the first bursary allocated by Raina (Regina) Kłokocka, née Mirska, the wife of the standard-bearer of Minsk. Being a bursary holder, he managed to go to Königsberg to study theology. The donor came from the well-off gentry involved in administering the country estates of the Radziwiłł family. She was the wife of Kazimierz Kłokocki, one of the three administrators of Ludwika Karolina Radziwiłłówna's country estates, and the daughter of Hrehory Mirski, the guardian of the Grand Duchy of Lithuania. The family provided generously for the education of Reformed youth, e.g. Hrehory's widow Katarzyna, née Kapaszczewska, donated all her books to Slutsk Grammar School, and Regina Mirska's sister Maria, the wife of the above mentioned Stanisław Niezabitowski, allotted 1,000 złoty (in 1705) to help educate young people. ${ }^{8}$ The University of Königsberg was very popular with Lithuanian youth, ${ }^{9}$ which resulted not from the short distance to cover, but the exceptionally friendly attitude of the Prussian authorities. Prince Albrecht reserved the right to give eight free places at the Collegium Albertinum to Lithuanian youths, who were expected to become priests on an assignment to introduce Protestant teaching to local people. ${ }^{10}$ When Dyjakiewicz went to university, three sons of priests, one Lithuanian speaker and two Polish speakers, could not be sponsored by the Radziwiłł Foundation because the foundation was established only in 1687 by Ludwika Karolina Radziwiłłowna. ${ }^{11}$ Each of the bursary holders was to receive

${ }^{7}$ Gabriel Dyjakiewicz enrolled in the first form of Slutsk Grammar School in 1680, while Jan Niezabitowski was in his second year then. See LMAB RS, F. 40, b. 148, Album scholae słucensis ab anno 1640 ad annum 1784, fo. 53 .

${ }^{8}$ LMAB RS, F. 40, b. 410, fo. 142. Regina Kłokocka was also the godmother of Dyjakiewicz' oldest son Marcin Stefan (b. 1690), and one of the Dyjakiewicz daughters was given the name of his sponsor (b. 1701), ibid., fo. 9, 10, 45 .

${ }^{9}$ In the years $1544-1828$ there were about 686 students from the Grand Duchy of Lithuania; A. Matulevičius, 'Deutsch-litauische Beziehungen', Annaberger Annalen, 13 (2005), p. 276.

${ }^{10}$ T. Grygier, 'Seminarium polskie w Królewcu', Komunikaty Mazursko-Warmińskie, 3, (1957), p. 129.

${ }^{11}$ LMAB RS, F. 40, b. 547, fo. 150, b. 596, fo. 26, Warsaw, Archiwum Główne Akt Dawnych, Archiwum Radziwitłów [AGAD AR], VIII, sygn. 710, p. 200, 207, 216, 236-237; the first bursary holders were: the son of the Nowogródek superintendent Taubman-Trzebicki, the son of the Węgrów minister Jan Krzysztof Krasinski, and the son of the Vilnius deputy superintendent Samuel Bythner; W. Hubatsch, Geschichte der evangelischen Kirche Ostpreussen (Göttingen, 1968), 142. 
50 thalers a year, but not on a one-off basis. According to Algirdas Matulevičius' research, Lithuanian students started to appear at the University of Königsberg quite early; there were five to eight of them in 1544-1545, while in 1546-1547 there were already 15 students. In the 16th century, about 202 students from Lithuania are listed in the immatriculation book, ${ }^{12}$ in the 17 th century, according to the author, there were 230 students from the Grand Duchy of Lithuania, and 19 students from Lithuania Minor (which makes 278 students altogether in the 17 th century), in the 18 th century, the number of students from Lithuania decreased to $201 .{ }^{13}$

Gabriel Dyjakiewicz studied in Königsberg for two years. He does not write much about his education in his memoirs. He mentions only that he spent the first year mainly on receiving private tuition from some of the local masters of arts, and in his second year he followed the mainstream curriculum.

In 1683 he set off from Pilau to Leiden by sea in order to continue his studies. ${ }^{14}$ Leiden University (founded in 1575) was very famous all over Europe. The rulers of the Republic managed to attract many eminent and renowned scholars, both natives and foreigners, thanks to the high salaries. The engineering school, observatory, botanical garden and excellent printing house were soon added to the traditional university departments in Leiden. The number of foreign students was on the increase. In 1625-1650, 52 per cent of the 11,076 students were foreigners. ${ }^{15}$ We do not know if Dyjakiewicz's journey from Königsberg to Leiden was financed with funds from Regina Kłokocka or how much it cost. We know that the Brethren allotted 200 złoty for travel expenses. ${ }^{16}$ Besides, the Lithuanian Brethren had four bursaries for theology students in Leiden at its disposal. We do not know any details; however, we can assume that they were of the kind available for students from the Greater Poland Brethren, which means that the Collegium Germanicum in Leiden provided students with accommodation in

${ }^{12}$ According to Antanas Musteikis, in the 16th century there were 233 Lithuanian students in Königsberg, A. Musteikis, The reformation in Lithuania. Religious Fluctuations in the Sixteenth Century (Boulder, 1988), p. 81.

${ }^{13}$ A. Matulevičius, 'Studenten aus Klein- und Großlitauen an der Universität Königsberg', Deutsch-litauische Beziehungen. Annaberger Annalen, 13 (2005), pp. 266, 271-2.

${ }^{14}$ LMAB RS, F. 40, b. 410, fo. 5.

15 J. Balicki, M. Bogucka, Historia Holandii (Wrocław, 1989), p. 212.

${ }^{16}$ LMAB RS, f. 40, b. 830, fo. 11. Synod session (damaged text) [1723]. 
a separate room and full board: meals at noon and in the evening, bread and butter in the morning. Also, students received six pounds of candles, six guldens and some stuivers a month; 28 guldens after submitting an annual writing assignment, and 200 guldens after submitting their final dissertation. ${ }^{17}$ It seems that an able and ambitious student could have a bright future ahead of him. Dyjakiewicz studied oriental languages, ${ }^{18}$ philosophy, theology and also subjects related to his future profession. ${ }^{19}$ In the years $1681-1690$, there were only two students from the Polish-Lithuanian Commonwealth that studied theology in Leiden (in the two previous decades there were none). In the 1690s, only 18 students from the Commonwealth studied in Leiden (at all the departments of the university), which means that there were not enough applicants for bursaries (even if we take into consideration only bursaries available for Lithuanian students). The greatest number of theology students (20) and students at other departments was reported in 1631-1640 (210). ${ }^{20}$

Studying at Protestant universities abroad was a necessity for a candidate for the priesthood, who had to graduate in theology, since there were no such universities in the Commonwealth. Synods suggested that alumni, especially bursary holders, should make a written commitment to study, first of all, philosophy and theology, with due diligence, as well as to complete their studies promptly. They were also expected to reject any job offers outside the Commonwealth. This attitude resulted, most probably, from the fact that students used to prolong their studies for various reasons, and sometimes felt tempted to accept a more gainful job offer in another country. They were constantly warned to guard their reputation. ${ }^{21}$ During his studies, a student should not indulge in numerous kinds of entertainment characteristic of affluent youth hoping for a worldly career. Instead, he should take an active part in academic life at his university. He should write all his essays and participate in debates, which were very popular then. A printed version of a

${ }^{17}$ Kriegseisen, Ewangelicy, p. 267.

${ }^{18}$ Leiden University used to be the world centre for oriental studies at that time, P. Zumthor, Życie codzienne $w$ Holandii $w$ czasach Rembrandta (Warsaw, 1965), p. 112.

${ }^{19}$ LMAB RS, F 40, b. 410, fo. 5.

${ }^{20}$ N. Hans, 'Polish Protestants and their Connections with England and Holland in the 17th and 18th Centuries', Slavonic and East European Review, 37 (1958), p. 216.

${ }^{21}$ LMAB RS, F. 40, b. 126, fo. 109, Synod in Bielica in June 1686 r. canon 10. 
dispute between Dyjakiewicz and Etienne Le Moyne, which was held in 1684, has been preserved. ${ }^{22}$ Le Moyne, a theology professor at Leiden Academy, of French origin, an Oxford graduate with a doctorate gained in Oxford in 1676, was very active in theological debates. ${ }^{23}$ The author is aware of printed versions of three disputes which were held in Leiden under the direction of Etienne Le Moyne. Each of them is 14-16 pages long, and was printed by Abraham Elzevier. ${ }^{24}$ We do not know if the debates were of any importance to Dyjakiewicz, but undoubtedly they confirm his participation in academic life.

Recollecting his voyage to Holland, Dyjakiewicz writes about a storm which struck his ship. Sea storms seem to be one of the most typical elements included in the memoirs of students at Dutch or English universities.

After having completed the three years of studies, Dyjakiewicz was summoned to return by the Synod of the Lithuanian Brethren, although he had declared earlier that he wanted to continue his education. He had to return because, most probably, before leaving for Leiden, he had made a written commitment to reimburse all the funds he received to cover his study expenses both at home and abroad if he decided not to serve the Calvinist Church in the congregation or as a teacher. There are a lot of such commitments preserved in the files of the Calvinist Synod, among others is the one signed by Jan, Dyjakiewicz's son. ${ }^{25}$

At the provincial Synod in Bielica in June 1686, the decision was reached to send him to Slutsk Grammar School as a deputy

${ }^{22}$ G. Dyjakiewicz, S. Le Moyne, Disputatio theologica II. de unione ecclesice cum pontifice Romano, an ea sit nota verce ecclesice?:, qvam, ... sub prcesidio ... Stephani le Moyne ..., apud Abrahamum Elzevier, 1684, p. 16.

${ }^{23} \mathrm{~J}$. van der Berg, Religious currents and cross-currents: essays on early modern Protestantism and the Protestant Enlightenment (Leiden, 1999), p. 167, L. van Poelgeest, 'The Stadholder-king William III and the University of Leiden', Fabrics and fabrications: the myth and making of William and Mary, ed. P. Hoftijzer and C.C. Barfoot (Amsterdam, 1990), pp. 126-7.

${ }^{24}$ Other people whose works developed as a result of debates with Le Moyne: Lubberus Waterham and Isbrandus Costrus (M.F.), most probably students at Leiden Academy, pupils of Le Moyne.

${ }^{25}$ E.g. the commitment of Gabriel Bieniaszewski, LMAB RS, F. 40, b. 548/2, fo. 143, who went to Leiden University after eight years of instruction in Slutsk Grammar School, in 1726 went to Edinburgh University, and then became a deputy rector in Kèdainiai Grammar School, Hans, 'Polish Protestants', p. 212. 
head teacher, ${ }^{26}$ while the head teacher was the Reverend Jerzy Lutomierski, the superintendent in Žemaitija and a minister (preacher) in Kedainiai. A year passed, and he became a lector, and was also ordained a deacon, thanks to the Reverend Krzysztof TaubmanTrzebicki's backing and support. Two years on, in 1688, at the provincial Synod in Zuprany, he was ordained a minister (preacher), again thanks to the Reverend Taubman-Trzebicki's efforts and backing, although he did not feel prepared to hold the position. The same Synod sent him to be a minister at the congregation in Žejmai in the Žemaitija district. ${ }^{27}$ The Calvinist Church suffered from a shortage of ministers, which explains why Dyjakiewicz was summoned from Leiden and ordained so hurriedly.

He obviously satisfied all the requirements and expectations, since a year later it was the Synod's decision to move him to Węgrów in the Podlasie district to work as an ordained minister (preacher). It was a considerable challenge for a young minister, because of the immediate vicinity of Warsaw and Mazovia, where there was a ban on erecting non-Catholic churches. As a result, priests from Wegrów were at the service of the Calvinist gentry and bourgeoisie in Warsaw during Parliament sessions. ${ }^{28}$ What is more, the church in Węgrów was also used by the Lutheran Church to hold services for its members, which was in accordance with the special privilege granted in 1651 by Duke Bogusław Radziwiłł. ${ }^{29}$ The rules on how to use the church and when to hold services and other ceremonies were established in 1653 in the form of an agreement between a minister, Maciej Apollos Styrzyński, and a pastor, Jonas Columbus, which made it possible for members of both confessions not to disturb one another. ${ }^{30}$ The sale of Węrów property to the Catholic Jan Kazimierz Krasiński, the treasurer of the Crown, in 1664, complicated considerably the situation of both confessions and caused growing problems, despite the fact that the church grounds

${ }^{26}$ LMAB RS, F. 40, b. 126, fos. $180 \mathrm{v}-109$, canon 8.

${ }^{27}$ LMAB RS, F. 40, b. 410 , fo. 6.

${ }^{28}$ PSB VI, p. 53.

${ }^{29}$ LMAB RS, F. 40, b. 113, fo. 1; Przywilej Bogusława Radziwiłła dla cudzoziemców chcących osiedlić się w Węgrowie, 14 kwietnia 1650 r., AGAD, AR, dz. VIII, sygn. 602, k. 7-8; H. Merczyng, Zbory i senatorowie protestanccy $w$ dawnej Rzeczypospolitej (Warsaw, 1904), p. 101; L. Otto, Przyczynek do historyi zboru ewangelicko-augsburskiego warszawskiego 1650-1781 (Warsaw, 1881), pp. 8-9.

${ }^{30} A G A D, A R$, dz. VIII, sygn. 602, fo. 5 . 
were excluded from the sale under the terms of the agreement. ${ }^{31}$ However, Krasinski brought in the Bernardines, who had experience in fighting heretics. When their attempts to create an atmosphere of hostility between the Catholic and Protestant communities turned out to be fruitless and unsuccessful, in 1678 they decided to burn down the 'fine and decorative' Calvinist church, which was built by Krzysztof II Radziwiłł ${ }^{32}$ a quarter of a century earlier. Although its reconstruction was forbidden by the local bishop, it was rebuilt, but in the form of a wooden 'shed'. ${ }^{33}$ When Dyjakiewicz arrived in Węgrów, the church was closed again on the orders of Stanisław Witwicki, the Bishop of Lutsk. It was reopened only four months after Dyjakiewicz's arrival, on 20 December $1689,{ }^{34}$ owing to the fact that the owner of Węgrów, Jan Bonawentura Krasiński, the wojewoda of Plotsk, interceded with the bishop on behalf of the Calvinist. The situation of the community worsened markedly after the death of Ludwika Karolina Radziwiłłówna. Both Dyjakiewicz and other Lithuanian Calvinists treated her death almost as a personal tragedy, aptly being worried that her Catholic heirs would not be willing to sponsor calvinist congregations. ${ }^{35}$ His administrative activities and involvement in the life of his parish ${ }^{36}$ helped him win recognition for his accomplishments by the Synod in Bielica in 1694, which ordained him a deputy superintendent in the Podlasie district. Rev. Filip Kopijewicz was ordained superintendent of the district at the same Synod. The position obliged him to make yearly inspections of Calvinist churches in his district, which enabled him to make some interesting observations. He was an acute observer, which can be noticed in the pages of his memoirs, ${ }^{37}$ full of descriptions of unusual atmospheric phenomena, but also of public events.

Another opportunity to obtain relevant information and make new contacts was regular visits to Warsaw during sessions of Parliament in order to minister to Calvinist members of Parliament. ${ }^{38}$ Surely

${ }^{31}$ LNMMB, F. 93, b. 893, fos. 98-99.

${ }^{32}$ Wyszomirski, 'Z Brzeszłosci', p. 137; MAB, F. 40, b. 410, fo. 61.

${ }^{33}$ Ibid.

${ }^{34}$ Ibid., fo. 8.

${ }^{35}$ Ibid., fo. 16 .

${ }^{36} A G A D$, AR, VIII, sygn. 602, fo. 51. In the years 1700-1704, Dyjakiewicz received $800 \mathrm{fl}$. a year to maintain the church.

${ }^{37}$ LMAB RS, F. 40, b. 410, fo. 14.

${ }^{38}$ Public services were held in the 'Brandenburg house', Wyszomierski, ' $\mathrm{Z}$ przeszłości’, p. 150. 
then he proved himself to be a trustworthy person, since around 1700 the superintendents of the Greater Poland Brethren requested him to organise a meeting of representatives of the authorities of both brethrens. ${ }^{39}$ Earlier, a similar suggestion was given to the Lithuanian Brethren by the superintendents of the Lesser Poland Brethren. ${ }^{40}$ Although the discussion was not initiated, the cooperation between the Greater Poland and Lithuanian brethrens was quite close, thanks to Dyjakiewicz. It gathered momentum when he established links with Daniel Ernest Jabłonski, the grandson of Jan Amos Komenski, a graduate of English universities, an outstanding Protestant irenist, the superintendent of the Bohemian Brethren in Poland since 1699, and a Lithuanian Calvinist elder. ${ }^{41}$ Jabłonski worked hard to bring about a union between the followers of different Protestant doctrines. He supported the idea of unifying the acts of faith and putting aside some minor differences. Dyjakiewicz was involved in arranging several meetings of the Calvinist and the Lutheran churches. He also engaged in actions meant to improve the legal situation of Protestants in the Commonwealth. He participated in provincial Synod meetings in Gdańsk on 2 September 1718 along with Jabłonski, ${ }^{42}$ and also in a Synod assembly of the Calvinist and the Lutheran churches in Kedainiai in April 1719. ${ }^{43}$ The detailed report of the assembly bears his signature.

Dyjakiewicz's activity in unifying Protestant confessions is not at all surprising. In his memoirs, we can read that he established a good social relationship with the pastor in Wegrów, who regularly baptised his children, while his Lutheran neighbours often acted as godparents. Some names are provided with comments, such as 'a good friend' or 'a good female friend'. What is more, in the final part of his memoirs, entitled 'extraordinary christening', he describes situations when he baptised an Arian child (in Stanisław

${ }^{39}$ Kriegseisen, Ewangelicy, p. 151.

${ }^{40}$ A letter from the Rev. Tomasz Rzepecki, the superintendent of Lesser Poland, and Stefan Żeleński, the burgrave of Krakow Castle and the chairman of the provincial parliament session, with the suggestion that the representatives of the authorities of both Brethrens should meet either in Orla or in Zabludow in the Podlasie district, from Sieczkow, 26 June 1684, LMAB RS, F. 40, b. 129, fo. 109.

${ }^{41}$ J. Szeruda, 'Jabłoński Daniel Ernest', PSB, X (Cracow, 1962-1964), p. 253.

${ }^{42}$ Warsaw University Library, Synod Ewangelicko-Reformanowego [BUW, SER], sygn. 1168 , fo. 14,

${ }^{43}$ Kriegseisen, Ewangelicy, pp. 153-60. 
Niezabitowski's manor house in Slutsk in 1714) or a Jewish child (in Węgrów in 1710). ${ }^{44}$

Gabriel Dyjakiewicz's son Marcin, meant to become a priest when he was still a child, ${ }^{45}$ a graduate of Berlin, Frankfurt am Oder and Leiden universities, then a minister and the head teacher (rector) of Kedainiai Grammar School, proved to be his father's praiseworthy successor. ${ }^{46}$

Marcin Dyjakiewicz, with all his activity, also deserves further research.

In conclusion, it should be stated that Gabriel Dyjakiewicz, the son of a Calvinist minister of modest means, could obtain a proper education only owing to bursaries granted both by private people (Kłokocka) and by the Lithuanian Brethren, not to mention the foreign funding. His diligence, abilities and hard work enabled him to complete his education, and also earned him the respect and wide recognition of the Calvinists in his parish and in the country. Contacts that he established and various bursaries that he was granted helped him send his sons to foreign universities. His oldest son Marcin, who became his praiseworthy successor, was his pride and joy.

\section{Author Details}

Elżbieta Bagińska PhD is a lecturer at the Institute of History and Political Science, University of Bialystok, and editorial secretary of the journal Podlasie Studies. She specialises in the history of the Calvinist Church in the Grand Duchy of Lithuania, and is interested in the history of the Middle Ages.

Address: Institute of History and Political Science, University of Bialystok, Pl. Uniwersytecki 1, 15-420 Białystok, Poland

e-mail: baginska@uwb.edu.pl

${ }^{44}$ LMAB RS, F. 40, b. 410 , fo. $60 \mathrm{v}$.

${ }^{45}$ Ibid., fo. 14. Entered Marburg University on 26 September 1711, U. Schoenbor, 'Horizonterweiterung. Litauische Stipendiaten in Marburg 1682-1822', Annaberger Annalen 13 (2005), p. 258.

${ }^{46}$ LMAB RS, F. 40, b. 410 , fo. 48. 
LIETUVOS DIDŽIOSIOS KUNIGAIKŠTYSTĖS EVANGELIKŲ REFORMATŲ STIPENDININKŲ KARJEROS. GABRIELIAUS DIJAKEVIČIAUS PAVYZDYS

Santrauka

\section{ELŻBIETA BAGIŃSKA}

Straipsnyje aptariama Lietuvos Didžiosios Kunigaikštystės evangelikų reformatų bažnyčios ministro Gabrieliaus Dijakevičiaus (Gabriel Dyjakiewicz) (1660-1724) profesinè karjera, kurią jis galèjo sèkmingai pradèti dèl jam suteiktos stipendijos. Tyrimas remiasi jo dienoraščiu, kuri jis rašè beveik per visą savo gyvenimą, taip pat - Lietuvos evangelikų reformatu sinodo dokumentais, kurių dauguma yra saugoma Lietuvos mokslų akademijos Vrublevskių bibliotekoje Vilniuje. Dijakevičiaus mokslo kelias susidejjo iš keliu etapų. Pirmiausia buvo vos dvejus metus trukęs mokymasis Slucko gimnazijoje, kur jis gavo privačią stipendiją, leidusią tęsti mokslus protestantiškuose universitetuose. Universitetini išsilavinimą igijo studijuodamas Karaliaučiaus universitete bei toliau gilindamas savo žinias Leideno universitete. Studijoms pastarajame Dijakevičius, tikètina, buvo gavęs Lietuvos evangelikų reformatų bendruomenès stipendiją. Straipsnyje trumpai apibūdinamas gimnazijos bei abiejų universitetu pobūdis ir stipendininkų pareigos.

Toliau aptariama Dijakevičiaus profesinè karjera ir jo visuomeninė veikla. Lietuvos evangelikų reformatų sinodui nutarus, Gabrielius Dijakevičius tapo Vengrovo evangelikų reformatų bažnyčios dvasininku. Vengrovas, nors buvo Lenkijos Karalystės Palenkès vaivadijoje, tačiau Palenkès evangelikų reformatų distriktas priklausė Lietuvos evangelikų reformatų provincijai. Gabrieliaus Dijakevičiaus veikla čia sutapo su katalikų bažnyčios intensyvios kovos su kitatikiais laikotarpiu. Šioje kovoje buvo naudojami i̇vairiausi metodai - nuo teismo procesų iki evangeliku reformatų bažnyčiu padeginèjimų. Savo visuomenine veikla Dijakevičius stengèsi pagerinti Respublikos protestantų bažnyčių teisinę padètị.

Gabrieliaus Dijakevičiaus sūnus Martynas po studijų Vakarų Europos protestantiškuose universitetuose tęsė tèvo darbą: iš pradžiu buvo Kẻdainių gimnazijos rektorius, vèliau tapo Vengrovo evangelikų reformatų bažnyčios dvasininku. 